\title{
Antenna standards and laboratories in Europe
}

\section{Lemanczyk, Jerzy}

\section{Published in:}

Digest. Conference on Precision Electromagnetic Measurements

Link to article, DOI:

10.1109/CPEM.1994.333351

Publication date:

1994

\section{Document Version}

Publisher's PDF, also known as Version of record

Link back to DTU Orbit

Citation (APA):

Lemanczyk, J. (1994). Antenna standards and laboratories in Europe. In Digest. Conference on Precision Electromagnetic Measurements (pp. 374-374). IEEE. https://doi.org/10.1109/CPEM.1994.333351

\section{General rights}

Copyright and moral rights for the publications made accessible in the public portal are retained by the authors and/or other copyright owners and it is a condition of accessing publications that users recognise and abide by the legal requirements associated with these rights.

- Users may download and print one copy of any publication from the public portal for the purpose of private study or research.

- You may not further distribute the material or use it for any profit-making activity or commercial gain

- You may freely distribute the URL identifying the publication in the public portal 
TH1B-1

\title{
ANTENNA STANDARDS AND LABORATORIES IN EUROPE
}

\author{
Jerzy Lemanczyk \\ Electromagnetics Institute \\ Technical University of Denmark \\ Building 348 \\ DK-2800 Lyngby, Denmark
}

\begin{abstract}
$\underline{\text { Abstract }}$
The goal of this paper will be to present an overview on antenna standards and laboratories within Europe. In this context, Europe will be limited geographically to the member nations of the European Union (EU), formerly the European Community, and the European Space Agency (ESA). In addition to these two instances, other parallel organizations in this field exist such as the Western European Laboratory Accreditation Cooperation (WELAC), the Western European Calibration Cooperation (WECC) which includes EUROMET, the European collaboration for measurement standards and the European Telecommunications Standards Institute (ETSI). And lastly, there are the national standards organizations and laboratories.
\end{abstract}

With regard to the EU, WELAC and WECC, work is concentrated more in the administrative and political arena with an aim to eliminating the various trade barriers which exist within the EU due to the lack of common laboratory accreditation and standards. None of these bodies operates or supports an antenna standards laboratory. However, the $\mathrm{EL}$ has established and operates the Joint Research Centre (JRC) which runs a new facility for microwave signature research related to radar, interferometry and remote sensing; here a data base is being built for standard $\sigma_{0}$ measurement results. ETSI, in the area of antennas, has produced European Telecommunication Standards for satellite earth stations and VSAT terminals which the EU has used as the basis for their Conformance Testing Services Program in the area of telecommunications.

The European Space Agency on the other hand has very specific requirements with respect to antenna measurements, standards as well as the qualification of antenna testing laboratories which carry out work under contract for them. The need for precise and accurate antenna measurements was already defined by ESA in the early 1970 's with feasibility studies into spherical near field antenna measurements being carried out at The Marconi Research Centre, UK and later at the
Electromagnetics Institute (EMI) of the Technical University of Denamrk (TUD). ESA concluded that near field measurements were the solution to the need for precise and accurate antenna measurements. EMI was able to make a substantial contribution in this direction as the theoretical basis for spherical near field measurements had already been formulated there in the late 1960 's.

From this work evolved the TUD-ESA Spherical Near Field Antenna Test Facility which since 1980 has been providing ESA contractors with calibrated standard gain horn antennas. Of note here is that the existence of this facility is largely unknown to the EU and other organs mentioned above and thus operates outside of their scope. ESA accepted standard gain horns calibrated at TUD as being primary standards to be used in antenna measurements. Due to this acceptance by ESA, other European companies have had their own standards calibrated at TUD, including probes for near antenna test ranges.

In the mid 1980's, TUD became more and more involved with antenna range intercomparisons in support of on going ESA antenna measurement programs; ESA had defined the need for the qualification of antenna test ranges being used to carry out antenna measurements for their programs. This collaborative effort between ESA and TUD is now proceeding on two parallel tracks. One is the definition and procurement of suitable antennas to be used in an antenna test range qualification.; thus the emergence of the ESA Validation Standard (VAST) antennas. The second track is the standardization of the validation procedure itself.

The aim of the VAST program is to establish a standardized and periodic qualification of antenna test ranges working for ESA projects. This standardization in conjunction with the set of VAST antennas will not only allow periodic evaluation of the functioning of antenna test ranges but will also allow for a controlled and systematic investigation into antenna measurement accuracies. 